\title{
Assessment of Xanthomonas arboricola pv. juglandis Bacterial Load in Infected Walnut Fruits by Quantitative PCR
}

\author{
Leonor Martins, ${ }^{1,2}$ Camila Fernandes, ${ }^{1,2,3}$ Pedro Albuquerque, ${ }^{1,2}$ and Fernando Tavares ${ }^{1,2, \dagger}$ \\ ${ }^{1}$ CIBIO - Centro de Investigação em Biodiversidade e Recursos Genéticos, InBIO - Laboratório Associado, Universidade do \\ Porto, Vairão, Portugal \\ ${ }^{2}$ FCUP - Faculdade de Ciências, Departamento de Biologia, Universidade do Porto, Porto, Portugal \\ ${ }^{3}$ INIAV - Instituto Nacional de Investigação Agrária e Veterinária, Quinta do Marquês, Oeiras, Portugal
}

\begin{abstract}
Xanthomonas arboricola pv. juglandis is the etiologic agent of important walnut (Juglans regia L.) diseases, causing severe fruit drop and high economic losses in walnut production regions. Rapid diagnostics and knowledge of bacterial virulence fitness are key to hinder disease progression and apply timely phytosanitary measures. This work describes an $X$. arboricola pv. juglandis-specific real-time quantitative PCR (qPCR) using $X$. arboricola pv. juglandis-specific DNA markers to quantify the bacterial load in infected walnut plant tissues. Method validation was achieved using calibration curves obtained with serial dilutions of $X$. arboricola pv. juglandis chromosomal DNA and standard curves obtained from walnut samples spiked

considering the calibration and standard curves, respectively. Assessment of qPCR repeatability, reproducibility, and specificity allowed us to demonstrate the reliability and consistency of the method. Furthermore, in planta quantification of $X$. arboricola pv. juglandis bacterial load using infected walnut fruit samples showed a higher detection resolution compared with standard PCR detection. By allowing quantification of virulence fitness of distinct $X$. arboricola pv. juglandis strains in planta, the proposed qPCR method may contribute to assertive risk assessment of walnut diseases caused by $X$. arboricola pv. juglandis and ultimately help to improve phytosanitary practices.
\end{abstract} with $X$. arboricola pv. juglandis cells. High correlations $\left(R^{2}>0.990\right.$ and $>0.995$ ) and low limits of detection (35 chromosomes/qPCR reaction and 2.7 CFU/qPCR reaction) were obtained for both markers
Keywords: DNA markers, qPCR, virulence, walnut diseases, Xanthomonas arboricola pv. juglandis
Xanthomonas arboricola pv. juglandis is the etiological agent of walnut bacterial blight, the most important bacterial disease of walnut (Juglans regia L.) (Frutos 2010). X. arboricola pv. juglandis has also been associated with brown apical necrosis (Moragrega et al. 2011) and vertical oozing canker diseases (Hajri et al. 2010), altogether causing major economic losses attributable to its worldwide distribution and persistence (Frutos and López 2012; Lamichhane 2014).

In the last decade, several studies emphasized the genetic diversity of $X$. arboricola pv. juglandis populations, contributing to improve our knowledge on the epidemic behavior of this pathogen (Cesbron et al. 2014; Fischer-Le Saux et al. 2015; Hajri et al. 2012; Ivanović et al. 2014). In addition, nonpathogenic $X$. arboricola lineages were isolated from symptomatic walnut trees. These genetically diverse

Current address of P. Albuquerque: I3S - Instituto de Investigação e Inovação em Saúde, Universidade do Porto, Porto, Portugal.

${ }^{\dagger}$ Corresponding author: F. Tavares; ftavares@fc.up.pt

Funding: This work was co-financed by the European Structural and Investment Funds (ESIFs) through the Operational Competitiveness and Internationalization Programme COMPETE 2020 and by National Funds through the Fundação para a Ciência e a Tecnologia (FCT), within the framework of the project EVOXANT (PTDC/BIA-EVF/3635/2014 and POCI-010145-FEDER-016600), and from the European Cooperation in Science and Technology (COST) action (EuroXanth CA16107). C. Fernandes was supported by a fellowship from FCT (SFRH/BD/95913/2013).

*The $\boldsymbol{e}$-Xtra logo stands for "electronic extra" and indicates that four supplementary figures are published online.

The author(s) declare no conflict of interest.

Accepted for publication 30 April 2019.

(C) 2019 The American Phytopathological Society strains were shown to group separately from the well-defined clusters of pathogenic $X$. arboricola pv. juglandis strains (Cesbron et al. 2015; Essakhi et al. 2015), also supporting differences in virulence (Giovanardi et al. 2016). Considering the high genetic diversity of $X$. arboricola strains and the isolation of related nonpathogenic bacteria, there is a need to characterize walnut-colonizing xanthomonads, taking into account their pathogenicity and virulence, to make robust risk assessments and contribute to implementation of timely and scientifically based phytosanitary practices.

Pathogenicity and virulence are often inaccurately used as synonyms and are sometimes inconsistently used in the scientific literature, leading to debates regarding the most appropriate definitions of these terms (Bos and Parlevliet 1995; Casadevall and Pirofski 1999; Shapiro-Ilan et al. 2005; Thomas and Elkinton 2004). Despite these disputes, the thorough revision made by Shapiro-Ilan et al. (2005) provides a coherent understanding of these two concepts, defining pathogenicity as the ability to cause disease, whereas virulence refers to pathogen fitness or its aptitude to colonize the host. Thus, although pathogenicity is a qualitative trait, virulence refers to the pathogen's capabilities to thwart the host's defenses, ultimately leading to a disease phenotype. Aligned with these definitions, some authors define virulence as inversely proportional to the number of microorganisms required to trigger infection (Casadevall and Pirofski 2001; Shapiro-Ilan et al. 2005). These and other related concepts frequently used in phytopathology were revisited in a thoughtful pedagogic essay addressing the above definitions (Surico 2013). Whatever the semantic understanding of pathogenicity and virulence, the interest in quantifying the bacterial load in infected tissues in order to determine the pathogen fitness of a given infective strain is irrefutable. Currently, most of the studies to determine virulence of phytopathogenic bacteria are based on a gradient scale of symptoms (Bandi et al. 2015; Frutos and López 2012). Although this procedure may provide a semiquantitative measure of virulence and might distinguish a poorly virulent strain from a highly virulent strain, it is dependent on a visual or phytopathometrical evaluation of the symptoms and is not suitable to accurately quantify the bacterial load. 
Quantitative PCR (qPCR) is a frequently used method in environmental microbiology to measure target DNA from environmental samples, using a standard curve plotted from known concentrations of target DNA (Pérez et al. 2013). Despite the existence of numerous real-time PCR methods established for several phytopathogens, the quantification of plant pathogenic microorganisms in infected plant material or in environmental matrices such as soils still lacks adequate optimization to assist plant disease management practices (Alemu 2014; Lievens et al. 2006).

Real-time PCR protocols have been widely used to detect and identify several members of the Xanthomonas genus, namely X. campestris (Berg et al. 2006), X. fragariae (Vandroemme et al. 2008; Weller et al. 2007), X. axonopodis pv. citri (Golmohammadi et al. 2007), X. oryzae pv. oryzae (Cho et al. 2011), X. arboricola pv. pruni
(Palacio-Bielsa et al. 2011, 2015) X. campestris pv. campestris (Laala et al. 2015), and X. axonopodis pv. allii (Robène et al. 2015). Despite the importance of these contributions, the qPCR potential beyond detection and identification of Xanthomonas species remains poorly explored. One exception has been a qPCR method developed to distinguish resistant and susceptible cultivars based on quantification of $X$. albilineans (Garces et al. 2014).

Advances concerning a framework to select taxon-specific DNA markers (i.e., DNA signatures) successfully validated for PCR-based detection of Xanthomonas species in infected plant samples (Albuquerque et al. 2012) further empower the development of qPCR approaches to determine the bacterial load in several host plants. Nine $X$. arboricola pv. juglandis-specific DNA markers (XAJ1 to XAJ9) were selected and

Table 1. List of bacteria strains used in this study

\begin{tabular}{|c|c|c|}
\hline Strain $^{z}$ & Geographic origin & Year of isolation \\
\hline \multicolumn{3}{|l|}{ Xanthomonas arboricola pv. juglandis } \\
\hline CFBP 176 & France & 1961 \\
\hline CFBP 877 & France & 1966 \\
\hline CFBP 2564 & Italy & 1985 \\
\hline CFBP 2632 & Spain & 1984 \\
\hline CFBP 5252 & France & 2000 \\
\hline CFBP 6556 & Italy & 1993 \\
\hline CFBP 6557 & Italy & 1999 \\
\hline CFBP 7072 & Spain & 1993 \\
\hline CFBP $7179^{\mathrm{GSS}}$ & France & 2002 \\
\hline CFBP 7244 & France & 1978 \\
\hline LMG 745 & The Netherlands & 1978 \\
\hline LMG 746 & United Kingdom & 1955 \\
\hline LMG 747T;GSS & New Zealand & 1956 \\
\hline LMG 748 & New Zealand & 1956 \\
\hline LMG 749 & New Zealand & 1957 \\
\hline LMG $751^{\mathrm{GSS} ; *}$ & Romania & 1962 \\
\hline LMG 752 & United Kingdom & 1964 \\
\hline LMG 8047 & The Netherlands & 1979 \\
\hline CPBF 1480 & Azeitão, Portugal & 2014 \\
\hline CPBF 1486 & Alcobaça, Portugal & 2014 \\
\hline CPBF 1492 & Alcobaça, Portugal & 2014 \\
\hline CPBF 1502 & Alcobaça, Portugal & 2014 \\
\hline CPBF 1527 & Estremoz, Portugal & 2014 \\
\hline CPBF 100 & Ponte da Barca, Portugal & 2015 \\
\hline CPBF 1514 & Estremoz, Portugal & 2014 \\
\hline \multicolumn{3}{|c|}{$X$. arboricola strains not belonging to the juglandis pathovar } \\
\hline X. arboricola pv. populi CFBP $3123^{\mathrm{PRS}}$ & The Netherlands & 1979 \\
\hline X. arboricola pv. pruni $\mathrm{LMG} 852^{\mathrm{PRS}}$ & New Zealand & 1953 \\
\hline X. arboricola pv. celebensis $\mathrm{LMG} 677^{\mathrm{PRS}}$ & New Zealand & 1960 \\
\hline X. arboricola pv. corylina $\mathrm{LMG} 689^{\mathrm{PRS}}$ & United States & 1939 \\
\hline X. arboricola pv. fragariae $\mathrm{LMG} 19145^{\mathrm{PRS}}$ & Italy & 1993 \\
\hline X. arboricola $\mathrm{CPBF} 122$ & Ponte da Barca, Portugal & 2015 \\
\hline X. arboricola $\mathrm{CPBF} 1530$ & Estremoz, Portugal & 2014 \\
\hline \multicolumn{3}{|l|}{ Other Xanthomonas strains } \\
\hline X. axonopodis pv. citri LMG $9322^{\mathrm{T}}$ & United States & 1989 \\
\hline X. axonopodis pv. dieffenbachiae LMG 695 PRS & Brazil & 1965 \\
\hline X. axonopodis pv. phaseoli LMG $7455^{\mathrm{PRS}}$ & United States & 1986 \\
\hline X. campestris pv. campestris LMG 568 & United Kingdom & 1957 \\
\hline X. euvesicatoria LMG 922 & United States & 1939 \\
\hline$X$. fragariae $\mathrm{LMG} 708^{\mathrm{T}}$ & United States & 1960 \\
\hline X. gardneri LMG $962^{\mathrm{GSS} ; \mathrm{T}}$ & Yugoslavia & 1953 \\
\hline X. oryzae pv. oryzae LMG 5047PRS & India & 1965 \\
\hline X. oryzae pv. oryzicola LMG 797 PRS & Malaysia & 1964 \\
\hline X. perforans $\mathrm{NCPPB} 4321^{\mathrm{T}}$ & United States & 1991 \\
\hline X. translucens pv. translucens LMG $876^{\mathrm{GSS} ; \mathrm{PRS}}$ & United States & 1933 \\
\hline X. vesicatoria $\mathrm{LMG} 911^{\mathrm{GSS} ; \mathrm{T}}$ & New Zealand & 1955 \\
\hline Xanthomonas sp. CPBF 367 & Loures, Portugal & 2016 \\
\hline Xanthomonas sp. CPBF 98 & Ponte da Barca, Portugal & 2015 \\
\hline Xanthomonas sp. CPBF 1488 & Alcobaça, Portugal & 2014 \\
\hline
\end{tabular}

${ }^{\mathrm{z}} \mathrm{CFBP}=$ French Collection for Plant-Associated Bacteria, Institut National de la Recherche Agronomique, Angers, France; GSS = genome sequenced strain; LMG = Belgian Coordinated Collections of Microorganisms/LMG Bacteria Collection, Universiteit Gent Laboratorium voor Microbiologie, Gent, Belgium; $\mathrm{T}=$ type strain; NCPPB = National Collection of Plant Pathogenic Bacteria, Fera Science Ltd., York, United Kingdom; CPBF = Colecção Portuguesa de Bactérias Fitopatogéncias, Oeiras, Portugal; and PRS, pathovar reference strain. The asterisk in LMG $751^{\mathrm{GSS} ; *}$ indicates other collection no. NCPPB 1447. 
validated in 2017 (Fernandes et al. 2017). Three of these markers (XAJ1, XAJ6, and XAJ8) were shown to efficiently detect $X$. arboricola pv. juglandis in naturally infected walnut leaves and fruits using a multiplex PCR approach (Fernandes et al. 2017), raising the opportunity to use these DNA markers to measure $X$. arboricola pv. juglandis virulence fitness from symptomatic walnut leaves and fruits.

In this work, we developed a qPCR method using two $X$. arboricola pv. juglandis-specific DNA markers able to quantify $X$. arboricola pv. juglandis bacterial load from infected walnut plant tissues and measure the virulence of distinct $X$. arboricola pv. juglandis strains. This method may contribute to the rapid identification of highly virulent $X$. arboricola pv. juglandis lineages or strains in walnut orchards, which is essential to take timely phytosanitary action and perform epidemiological risk assessments of $X$. arboricola pv. juglandis-causing diseases.

\section{Materials and Methods}

Bacterial cultures and DNA extraction. The bacterial strains used in this study included $25 \mathrm{X}$. arboricola pv. juglandis strains, seven $X$. arboricola strains not belonging to the juglandis pathovar, and 15 strains of other Xanthomonas species (Table 1). Single colonies were grown in nutrient broth $(2 \mathrm{~g} /$ /iter of yeast extract, $5 \mathrm{~g} /$ liter of peptone, $5 \mathrm{~g} /$ liter of $\mathrm{NaCl}, 0.45 \mathrm{~g} /$ liter of $\mathrm{KH}_{2} \mathrm{PO}_{4}$, and $2.29 \mathrm{~g} /$ liter of $\mathrm{Na}_{2} \mathrm{HPO}_{4} \cdot 12 \mathrm{H}_{2} \mathrm{O}$ ) and DNA was extracted using the E.Z.N.A. Bacterial DNA Kit (Omega Bio-Tek, Norcross, GA), following the manufacturer's instructions. DNA quantification was carried out using the Qubit 2.0 fluorometer (Invitrogen, Carlsbad, CA).

Walnut fruit inoculation with $X$. arboricola pv. juglandis and bacterial DNA extraction. Immature walnut fruits from a single walnut tree (phenophases Gf +30 and Gf +45 , Mikulic-Petkovsek et al. 2011) without symptomatic lesions were used in this study. The fruits were disinfected by immersion in $70 \%$ ethanol for $30 \mathrm{~s}$ and were thoroughly washed with sterile distilled water. Five groups of four walnut fruits each were tested. The fruits were inoculated by immersion in an $X$. arboricola pv. juglandis LMG $747^{\mathrm{T}}$ bacterial suspension of approximately $10^{8} \mathrm{CFU} / \mathrm{ml}$ for up to $30 \mathrm{~min}$ at room temperature with slow shaking. As negative controls, the fruits were immersed in sterile distilled water for $30 \mathrm{~min}$, following the same conditions as described above. After inoculation, the fruits were incubated under controlled environmental conditions (16-h/8-h photoperiod and a temperature of $24^{\circ} \mathrm{C} / 18^{\circ} \mathrm{C}$ ) in sterile individual plastic containers to ensure high humidity. After 2 weeks, all fruits inoculated with $X$. arboricola pv. juglandis LMG $747^{\mathrm{T}}$ showed clear disease symptoms. One fruit from each group was then divided into eight identical parts by two longitudinal sections passing through the fruit apical scar (micropile) followed by an equatorial section (Fig. 1). For DNA extraction, the outer pericarp layer (external fruit green husk containing the lesions) of each selected fruit fraction was excised with a sterile scalpel, the weight of tissue recovered was registered, and the fraction was then macerated with $5 \mathrm{ml}$ of sterile distilled water in extraction bags (Bioreba AG, Reinach, Switzerland). Then $2 \mathrm{ml}$ of the extract was centrifuged at $16,000 \times g$ for $10 \mathrm{~min}$ to obtain a bacterial pellet used for DNA extraction using the DNeasy Plant Mini Kit (Qiagen, Hilden, Germany) following the manufacturer's instructions.

Selection of $X$. arboricola pv. juglandis-specific DNA markers for qPCR. Eighteen fully sequenced genomes of $X$. arboricola pv. juglandis were surveyed for the presence of $X$. arboricola pv. juglandisspecific DNA markers (XAJ1 to XAJ9) previously characterized by Fernandes et al. (2017): NCPPB 1447 (NZ_AJTL00000000.1), CFBP 2528 (NZ_JZEF00000000.1), CFBP 7179 (JZEG01000001.1), CFSAN033077 (NZ_LHBK00000000.1), CFSAN033081 (NZ_ LHBO00000000.1), CFSAN033086 (NZ_LHBT00000000.1), J303 (NZ_LSGZ00000000.1), 417 (CP012251.1), CFSAN033078 (NZ_LHBL00000000.1), CFSAN033079 (NZ_LHBM00000000.1), CFSAN033080 (NZ_LHBN00000000.1), CFSAN033082 (NZ LHBP00000000.1), CFSAN033083 (NZ_LHBQ00000000.1), CFSAN033084 (NZ_LHBR00000000.1), CFSAN033085 (NZ_ LHBS00000000.1), CFSAN033087 (NZ_LHBU00000000.1), CFSAN033088 (NZ_LHBV00000000.1), and CFSAN033089 (NZ_LHBW00000000.1) (Supplementary Fig. S1). The occurrence of these nine $X$. arboricola pv. juglandis-specific markers was further evaluated in $108 \mathrm{X}$. arboricola pv. juglandis isolates (Fernandes et al. 2018) (Supplementary Fig. S2). The matrices assembled based on the data gathered showed that four markers (XAJ1, XAJ4, XAJ6, and XAJ8) were present in most of the X. arboricola pv. juglandis strains, but only XAJ1 and XAJ6 were present in all X. arboricola pv. juglandis strains analyzed and therefore were chosen as the most promising for $\mathrm{qPCR}$.

PCR-based confirmation of walnut fruit infection by $X$. arboricola pv.juglandis. Infection of fruits by $X$. arboricola $\mathrm{pv}$. juglandis LMG $747^{\mathrm{T}}$ was confirmed by PCR using the primer pairs XAJ1F/ XAJ1R and XAJ6F/XAJ6R to target XAJ1 and XAJ6 DNA markers as previously described (Fernandes et al. 2017) (Table 2). PCR reactions were carried out in $20 \mu \mathrm{l}$ reactions containing $1 \times$ DreamTaq Buffer (Thermo Scientific, Vilnius, Lithuania), $0.2 \mathrm{mM}$ of each dNTP (Thermo Scientific), $0.2 \mu \mathrm{M}$ of each primer (STAB Vida, Lisbon, Portugal), 1 U of DreamTaq DNA Polymerase (Thermo Scientific), and $2 \mu l$ of DNA extracted from infected fruit fractions. PCR was performed with an initial $5 \mathrm{~min}$ denaturation at $95^{\circ} \mathrm{C}$, followed by 35 cycles of $30 \mathrm{~s}$ at $95^{\circ} \mathrm{C}, 30 \mathrm{~s}$ at $61^{\circ} \mathrm{C}$, and $30 \mathrm{~s}$ of extension at $72^{\circ} \mathrm{C}$, with a final extension step of $10 \mathrm{~min}$ at $72^{\circ} \mathrm{C}$. PCR products were separated on $0.8 \%$ agarose gels stained with GreenSafe Premium (Nzytech, Lisbon, Portugal).

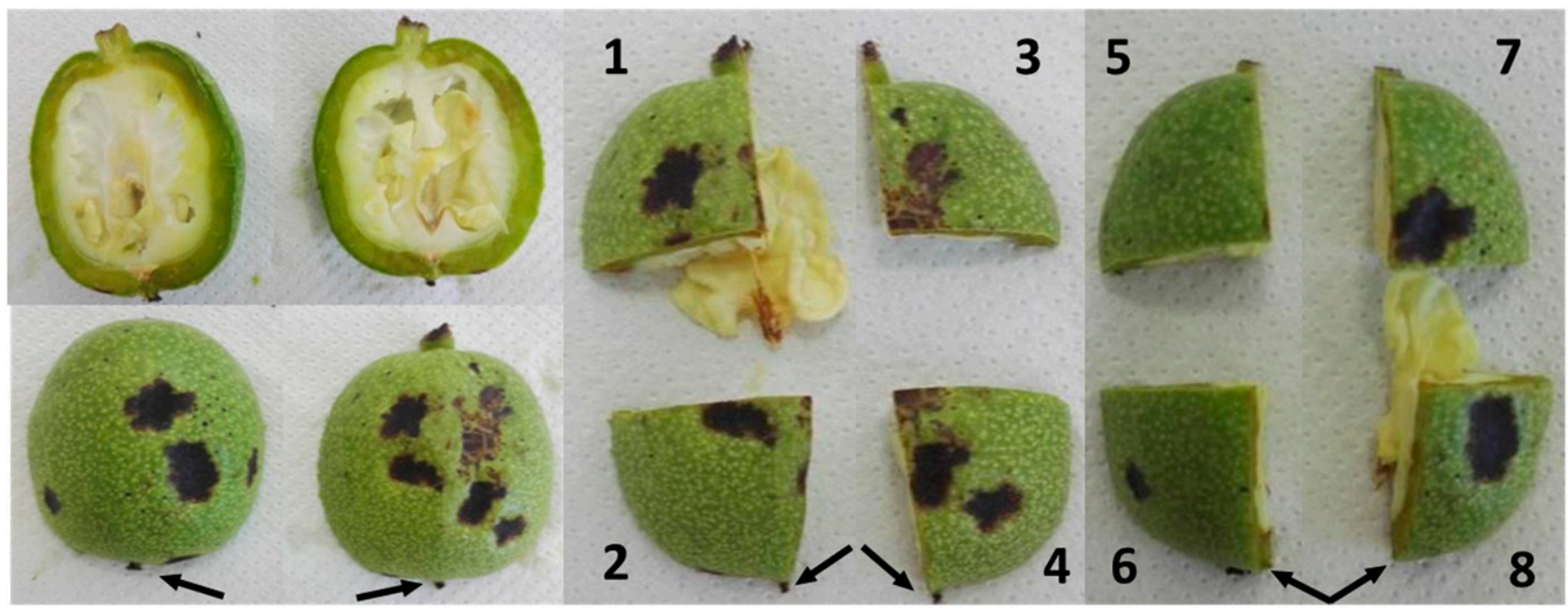

Fig. 1. Walnut fruit symptoms of Xanthomonas arboricola pv. juglandis infection. Each fruit was divided into eight parts (numbered 1 to 8 ). Arrows indicate the fruit apical scar. 
qPCR calibration curves with XAJ1 and XAJ6 markers. Two new primer pairs (XAJ1qPCR_Fwd/XAJ1qPCR_Rev and XAJ6qPCR_Fwd/ XAJ6qPCR_Rev) targeting a smaller fragment of X. arboricola pv. juglandis-specific markers XAJ1 (100 bp) and XAJ6 (101 bp) were designed for qPCR amplification (Table 2) using Geneious software (version 7.1.2; Biomatters, Auckland, New Zealand). Optimal annealing temperatures were determined based on the melting curves using both pairs of primers (Supplementary Fig. S3). qPCR calibration curves were constructed using serial dilutions $\left(1\right.$ to $\left.10^{-7}\right)$ of $X$. arboricola pv. juglandis LMG $747^{\mathrm{T}}$ DNA by plotting the quantification cycle $(\mathrm{Cq})$ versus the number of DNA marker copies. Each dilution was assessed in triplicate and the number of $X$. arboricola pv. juglandis chromosomes per microliter was calculated using the Science Primer copy number calculator for real-time PCR (http://scienceprimer.com). Each real-time PCR reaction contained $1 \times$ Sso Advanced Universal SYBR Green Supermix (Bio-Rad, Hercules, CA), $0.35 \mu \mathrm{M}$ of each primer, $1 \mu \mathrm{l}$ of each DNA template dilution, and nuclease-free water to a total volume of $20 \mu \mathrm{l}$. Reactions were carried out in hard-shell PCR plates (96well, white shell/clear well), sealed with Microseal B Adhesive Sealer (Bio-Rad). qPCR cycle conditions were as follows: initial denaturation step of $98^{\circ} \mathrm{C}$ for $3 \mathrm{~min}, 39$ cycles of $98^{\circ} \mathrm{C}$ for $10 \mathrm{~s}$ and $63^{\circ} \mathrm{C}$ for $30 \mathrm{~s}$, and a final melting curve analysis from 65 to $95^{\circ} \mathrm{C}$, with $0.5^{\circ} \mathrm{C}$ increments for $5 \mathrm{~s}$ per step. A nontemplate control was included in each run. Reactions were carried out in a CFX Connect Real-Time Detection System (Bio-Rad) and results were analyzed using CFX Manager software (version 3.1; Bio-Rad).

Validation of qPCR with spiked walnut leaf samples. Spiked walnut leaf samples were used for $\mathrm{qPCR}$ validation and inferred the presence of possible PCR inhibitors in plant extracts. $X$. arboricola pv. juglandis LMG $747^{\mathrm{T}}$ cells were grown in nutrient agar (NA) medium (Difco Laboratories, Detroit, MI) to an optical density of 0.135 at $\lambda=600$, corresponding to approximately $10^{8} \mathrm{CFU} / \mathrm{ml}$ as estimated by plating serial dilutions of the bacterial culture in NA at $28^{\circ} \mathrm{C}$. Spiked walnut leaf samples were prepared by mixing $X$. arboricola pv. juglandis LMG $747^{\mathrm{T}}$ cells recovered from $2 \mathrm{ml}$ of each dilution $\left(10^{7} \mathrm{CFU} / \mathrm{ml}\right.$ to $\left.10^{0} \mathrm{CFU} / \mathrm{ml}\right)$ after a centrifugation at 7,000 $\times g$ for $5 \mathrm{~min}$ with $2 \mathrm{ml}$ of bacteria-free plant extract. DNA from each spiked sample (i.e., sample processing control [SPC]) was extracted using the Qiagen DNeasy Plant Mini Kit as mentioned above and amplified in triplicate to construct a calibration curve for each marker (XAJ1 and XAJ6). The limit of detection (LOD) was determined as the CFU value of the dilution corresponding to the last linear point of the standard curve (Marancik and Wiens 2013). qPCR reactions and data analysis were carried out as described in the previous section.

qPCR repeatability, reproducibility, and analytical specificity. qPCR repeatability (intra-assay variance) and reproducibility (interassay variance) were assessed according to Bustin et al. (2009). Intra-assay

Table 2. Xanthomonas arboricola $\mathrm{pv}$. juglandis-specific markers used in this study ${ }^{\mathrm{z}}$

\begin{tabular}{|c|c|c|c|c|}
\hline DNA marker & Primer & Sequence $\left(5^{\prime}\right.$ to $\left.3^{\prime}\right)$ & Amplicon length (bp) & Source \\
\hline \multirow[t]{4}{*}{ XAJ1 } & XAJ1qPCR_Fwd & AGACGCGTCACTTCGGAAAGAG & 100 & This study \\
\hline & XAJ1qPCR_Rev & CCAGCCTGTTCTAGGTGGTTTG & & \\
\hline & XAJ1F & GTTGTCAAGGTCGCTACTGGACGC & 758 & Fernandes et al. (2017) \\
\hline & XAJ1R & CGACAGGTACCGAAAGTGGACG & & \\
\hline \multirow[t]{4}{*}{ XAJ6 } & XAJ6qPCR_Fwd & AGAGATTGATGAGCGATGCGAG & 101 & This study \\
\hline & XAJ6qPCR_Rev & GCACAGCGGGAAGTAATAGCAA & & \\
\hline & XAJ6F & AAGTCAGATGCGAAGCGAAAGG & 436 & Fernandes et al. (2017) \\
\hline & XAJ6R & GCACAGCGGGAAGTAATAGCAAAC & & \\
\hline
\end{tabular}

${ }^{\mathrm{z}} \mathrm{F}=$ forward and $\mathrm{R}=$ reverse.

Table 3. DNA marker XAJ1 repeatability and reproducibility of the quantitative PCR assay

\begin{tabular}{|c|c|c|c|c|c|c|c|c|c|}
\hline \multirow[b]{2}{*}{ Sample ${ }^{\mathrm{z}}$} & \multirow[b]{2}{*}{ 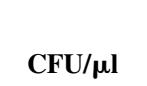 } & \multicolumn{4}{|c|}{ Intra-assay CV } & \multicolumn{4}{|c|}{ Interassay CV } \\
\hline & & Assays (n) & Mean Cq & SD & $\% \mathrm{CV}$ & Assays (n) & Mean Cq & SD & $\% \mathrm{CV}$ \\
\hline SPC-0 & $2.70 \times 10^{5}$ & 3 & 17.41 & 0.10 & 0.58 & 3 & 17.22 & 0.23 & 1.36 \\
\hline SPC-1 & $2.70 \times 10^{4}$ & 3 & 20.73 & 0.14 & 0.68 & 3 & 20.50 & 0.27 & 1.32 \\
\hline SPC-2 & $2.70 \times 10^{3}$ & 3 & 23.73 & 0.14 & 0.58 & 3 & 23.59 & 0.19 & 0.79 \\
\hline SPC-3 & $2.70 \times 10^{2}$ & 3 & 27.36 & 0.17 & 0.60 & 3 & 27.01 & 0.35 & 1.31 \\
\hline SPC-4 & $2.70 \times 10^{1}$ & 3 & 30.55 & 0.43 & 1.39 & 3 & 30.35 & 0.55 & 1.80 \\
\hline SPC-5 & $2.70 \times 10^{0}$ & 3 & 35.36 & 0.25 & 0.72 & 3 & 34.20 & 1.26 & 3.67 \\
\hline SPC-6 & $2.70 \times 10^{-1}$ & 3 & 35.68 & $\mathrm{n} / \mathrm{a}$ & $\mathrm{n} / \mathrm{a}$ & 3 & 35.48 & 0.57 & 1.62 \\
\hline SPC-7 & $2.70 \times 10^{-2}$ & 3 & $\mathrm{n} / \mathrm{a}$ & $\mathrm{n} / \mathrm{a}$ & $\mathrm{n} / \mathrm{a}$ & 3 & 35.71 & $\mathrm{n} / \mathrm{a}$ & $\mathrm{n} / \mathrm{a}$ \\
\hline
\end{tabular}

${ }^{\mathrm{y}} \mathrm{CV}=$ coefficient of variation, $\mathrm{Cq}=$ quantification cycle, $\mathrm{SPC}=$ sample processing control, and $\mathrm{n} / \mathrm{a}=$ not amplified.

${ }^{\mathrm{z}}$ The SPC dilutions within the linear range of the standard curve are shown in bold.

Table 4. DNA marker XAJ6 repeatability and reproducibility of the quantitative PCR assay

\begin{tabular}{|c|c|c|c|c|c|c|c|c|c|}
\hline \multirow[b]{2}{*}{ Sample ${ }^{z}$} & \multirow[b]{2}{*}{ 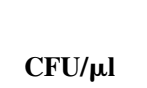 } & \multicolumn{4}{|c|}{ Intra-assay CV } & \multicolumn{4}{|c|}{ Interassay CV } \\
\hline & & Assays (n) & Mean Cq & SD & $\% \mathrm{CV}$ & Assays (n) & Mean Cq & SD & $\% \mathrm{CV}$ \\
\hline SPC-0 & $2.70 \times 10^{5}$ & 3 & 16.79 & 0.03 & 0.16 & 3 & 16.85 & 0.26 & $\overline{1.54}$ \\
\hline SPC-1 & $2.70 \times 10^{4}$ & 3 & 20.06 & 0.12 & 0.60 & 3 & 20.03 & 0.22 & 1.08 \\
\hline SPC-2 & $2.70 \times 10^{3}$ & 3 & 23.31 & 0.10 & 0.43 & 3 & 23.31 & 0.24 & 1.05 \\
\hline SPC-3 & $2.70 \times 10^{2}$ & 3 & 26.67 & 0.04 & 0.14 & 3 & 26.66 & 0.14 & 0.54 \\
\hline SPC-4 & $2.70 \times 10^{1}$ & 3 & 29.84 & 0.18 & 0.61 & 3 & 29.78 & 0.37 & 1.23 \\
\hline SPC-5 & $2.70 \times 10^{0}$ & 3 & 31.66 & 0.14 & 0.43 & 3 & 31.81 & 0.49 & 1.55 \\
\hline SPC-6 & $2.70 \times 10^{-1}$ & 3 & 34.89 & 0.53 & 1.53 & 3 & 33.80 & 1.02 & 3.02 \\
\hline SPC-7 & $2.70 \times 10^{-2}$ & 3 & 35.05 & 0.23 & 0.64 & 3 & 34.00 & 1.10 & 3.22 \\
\hline
\end{tabular}

${ }^{\mathrm{y}} \mathrm{CV}=$ coefficient of variation, $\mathrm{Cq}=$ quantification cycle, $\mathrm{SPC}=$ sample processing control, and $\mathrm{n} / \mathrm{a}=$ not amplified.

${ }^{\mathrm{z}}$ The SPC dilutions within the linear range of the standard curve are shown in bold. 
variation was calculated considering three replicates in a single run/ plate and interassay variation was calculated using three independent experiments with three replicates each (Table 3 and 4). Coefficients of variation $(\mathrm{CVs})$ were calculated according to the following formula: $\mathrm{CV}=$ standard deviation $\mathrm{Cq}$ values/average $\mathrm{Cq}$ (Robène et al. 2015).

Analytical specificity evaluates the detection of target DNA relatively to nontarget DNA sequences (Bustin et al. 2009) and was validated by taking into consideration the $\mathrm{Cq}$ value variations and/or differences between target (i.e., X. arboricola pv. juglandis) and nontarget bacteria (i.e., other $X$. arboricola strains not belonging to the juglandis pathovar and other Xanthomonas species). Accordingly, for this analysis, DNA from reference Xanthomonas strains isolated from different geographic regions was used, including 25 $X$. arboricola pv. juglandis strains, seven $X$. arboricola strains not belonging to the juglandis pathovar, and 15 strains of other Xanthomonas species (Table 5). DNA extraction and quantification was carried out as described above, and $20 \mathrm{ng}$ of DNA was used for each qPCR reaction. Melting curves to confirm primer pair specificity for both markers (XAJ1 and XAJ6) and for each tested strain were

Table 5. Quantitative PCR assay specificity for XAJ1 and XAJ6 markers: Comparative analysis of quantification cycle (Cq) values obtained for target groups (Xanthomonas arboricola pv. juglandis strains) and nontarget groups (other X. arboricola strains and other Xanthomonas strains) ${ }^{\mathrm{z}}$

\begin{tabular}{|c|c|c|c|c|}
\hline \multirow[b]{2}{*}{ Strain } & \multicolumn{2}{|c|}{ XAJ1 } & \multicolumn{2}{|c|}{ XАJ6 } \\
\hline & $\mathrm{Cq}$ & Mean \pm SD & $\mathbf{C q}$ & Mean \pm SD \\
\hline \multicolumn{5}{|l|}{ X. arboricola pv. juglandis } \\
\hline CFBP 176 & 13.76 & & 13.43 & \\
\hline CFBP 2564 & 14.06 & & 13.42 & \\
\hline CFBP 2632 & 13.74 & & 13.46 & \\
\hline CFBP 5252 & 13.81 & & 13.76 & \\
\hline CFBP 6556 & 13.68 & & 13.28 & \\
\hline CFBP 6557 & 13.22 & & 13.09 & \\
\hline CFBP 7072 & 13.69 & & 13.07 & \\
\hline CFBP 7179 & 13.66 & & 13.16 & \\
\hline CFBP 7244 & 13.91 & & 13.56 & \\
\hline CFBP 877 & 13.92 & & 13.60 & \\
\hline LMG 745 & 14.47 & & 13.80 & \\
\hline LMG 746 & 13.91 & $13.38 \pm 1.00$ & 13.70 & $13.12 \pm 0.84$ \\
\hline LMG 747 & 11.02 & & 11.56 & \\
\hline LMG 748 & 13.22 & & 12.68 & \\
\hline LMG 749 & 13.67 & & 13.11 & \\
\hline LMG 751 & 13.36 & & 12.73 & \\
\hline LMG 752 & 13.20 & & 12.92 & \\
\hline LMG 8047 & 13.75 & & 13.45 & \\
\hline CPBF 1480 & 10.17 & & 9.89 & \\
\hline CPBF 1486 & 14.31 & & 13.80 & \\
\hline CPBF 1492 & 13.69 & & 13.77 & \\
\hline CPBF 1502 & 13.33 & & 13.09 & \\
\hline CPBF 1527 & 13.96 & & 13.51 & \\
\hline CPBF 100 & 13.43 & & 13.12 & \\
\hline CPBF 1514 & 11.63 & & 32.98 & \\
\hline \multicolumn{5}{|l|}{$\begin{array}{l}\text { X. arboricola strains not belonging to the } \\
\text { juglandis pathovar }\end{array}$} \\
\hline X. arboricola pv. populi CFBP 3123 & 29.56 & & 29.21 & \\
\hline X. arboricola pv. pruni LMG 852 & $\mathrm{n} / \mathrm{a}$ & & $\mathrm{n} / \mathrm{a}$ & \\
\hline X. arboricola pv. celebensis LMG 677 & 12.22 & & 35.56 & \\
\hline X. arboricola pv. corylina LMG 689 & 19.96 & & 37.69 & \\
\hline X. arboricola pv. fragariae LMG 19145 & 35.75 & & $\mathrm{n} / \mathrm{a}$ & \\
\hline X. arboricola $\mathrm{CPBF} 122$ & 32.48 & & 31.47 & \\
\hline X. arboricola $\mathrm{CPBF} 1530$ & 37.63 & & 36.00 & \\
\hline \multicolumn{5}{|l|}{ Other Xanthomonas strains } \\
\hline X. axonopodis pv. citri LMG 9322 & 35.32 & & 31.97 & \\
\hline X. axonopodis pv. phaseoli LMG $7455^{\mathrm{PRS}}$ & 36.78 & & 39.78 & \\
\hline X. campestris pv. campestris LMG 568 & 33.03 & & 34.41 & \\
\hline X. fragariae LMG 708 & 37.82 & & $\mathrm{n} / \mathrm{a}$ & \\
\hline X. gardneri LMG 962 & 34.84 & & 34.84 & \\
\hline X. vesicatoria LMG 911 & 35.56 & & $\mathrm{n} / \mathrm{a}$ & \\
\hline X. axonopodis pv. dieffenbachiae LMG 695 & $\mathrm{n} / \mathrm{a}$ & & 35.70 & \\
\hline X. euvesicatoria LMG 922 & $\mathrm{n} / \mathrm{a}$ & & 35.56 & \\
\hline X. oryzae pv. oryzae LMG $5047^{\mathrm{PRS}}$ & $\mathrm{n} / \mathrm{a}$ & & $\mathrm{n} / \mathrm{a}$ & \\
\hline X. oryzae pv. oryzicola LMG 797 & $\mathrm{n} / \mathrm{a}$ & & 35.58 & \\
\hline X. perforans NCPPB 4321 & $\mathrm{n} / \mathrm{a}$ & & 35.10 & \\
\hline X. translucens pv. translucens LMG 876 & $\mathrm{n} / \mathrm{a}$ & & 36.71 & \\
\hline Xanthomonas sp. CPBF 98 & 12.94 & & 29.96 & \\
\hline Xanthomonas sp. CPBF 1488 & 31.04 & & 30.36 & \\
\hline Xanthomonas sp. CPBF 367 & 37.66 & & 36.30 & \\
\hline
\end{tabular}

${ }^{\mathrm{z}} \mathrm{CFBP}=$ French Collection for Plant-Associated Bacteria, Institut National de la Recherche Agronomique, Angers, France; LMG = Belgian Coordinated Collections of Microorganisms/LMG Bacteria Collection, Universiteit Gent Laboratorium voor Microbiologie, Gent, Belgium; CPBF = Colecção Portuguesa de Bactérias Fitopatogéncias, Oeiras, Portugal; $\mathrm{n} / \mathrm{a}=$ not amplified; PRS, pathovar reference strain; and NCPPB = National Collection of Plant Pathogenic Bacteria, Fera Science Ltd., York, United Kingdom. 
determined in duplicate (Supplementary Fig. S4). DNA extraction and quantification was carried out as described above, and $20 \mathrm{ng}$ of DNA was used for each qPCR reaction. Melting curves to confirm primer pair specificity for both markers (XAJ1 and XAJ6) and for each tested strain were determined in duplicate. qPCR reaction efficiency was calculated according to the following curve fitting method (Kralik and Ricchi 2017): Percent efficiency $=\left(10^{(-1 / m)}-\right.$ $1) \times 100$, where $m$ is the slope of the linear regression equation of the standard curve.

qPCR quantification of $X$. arboricola pv. juglandis in infected walnut fruits. To estimate the number of $X$. arboricola $\mathrm{pv}$. juglandis cells by qPCR in infected walnut fruit tissues, standard curves obtained from serial dilutions of SPCs for both XAJ1 and XAJ6 markers were generated as described above.

The qPCR reaction for each $X$. arboricola pv. juglandis-infected one-eighth fruit part contained $1 \times$ Sso Advanced Universal SYBR Green Supermix (Bio-Rad), $0.35 \mu \mathrm{M}$ of each primer, $2 \mu 1$ of template DNA, and nuclease-free water to a total volume of $20 \mu \mathrm{l}$. qPCR reactions were carried out in triplicate and in parallel with the SPC standard curves. CFX Manager software (version 3.1) was used to analyze the data and to calculate the efficiency of the qPCR reaction and the correlation coefficient $\left(R^{2}\right)$ of SPC standard curves. The absolute copy number for each marker in each fruit sample was calculated considering that each marker (XAJ1 and XAJ6) occurs as a single copy locus in $X$. arboricola pv. juglandis genomes and using the following formula:

$$
\text { Copy number }=10^{((\mathrm{Cq}-b) / \mathrm{m})} \text {. }
$$

This formula is derived from the linear regression equation of the standard curve:

$$
\mathrm{Cq}=m(\log \text { copy number })+b,
$$

where $\mathrm{Cq}$ is the quantification cycle value obtained for the tested sample, $m$ is the slope, and $b$ is the $y$-intercept of the linear

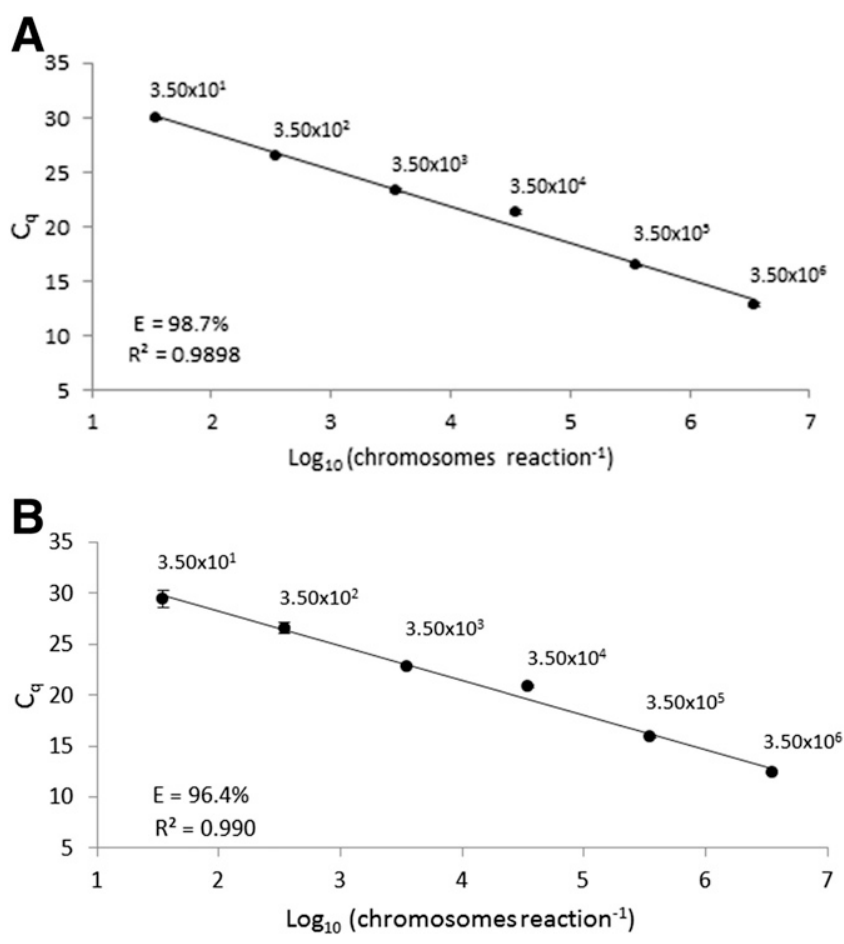

Fig. 2. Calibration curves for $A, X A J 1$ and $B, X A J 6$ DNA markers obtained from serial dilutions of Xanthomonas arboricola pv. juglandis strain LMG 747 DNA. The linear portion of the curve ranged from $3.5 \times 10^{6}$ to 35 chromosomes/ $\mu$. The efficiency $(E)$ of the qPCR assays was 98.7 and $96.4 \%$ for XAJ1 and XAJ6, respectively. The correlation efficiency $\left(R^{2}\right)$ was 0.990 for XAJ1 and 0.990 for XAJ6. Standard deviations at each point are represented in the figure. $\mathrm{Cq}=$ quantification cycle. regression equation of the calibration curve. The results were expressed as the number of $X$. arboricola $\mathrm{pv}$. juglandis chromosomes or the cell number (X. arboricola pv. juglandis load) per gram of fruit fresh weight for each one-eighth fruit part. $X$. arboricola pv. juglandis bacteria load per fruit was determined as the average $X$. arboricola pv. juglandis load per gram of fresh weight obtained for the eight fruit parts and the corresponding standard deviation.

Statistical analysis. IBM SPSS Statistics software (version 25) was used to perform all statistical analyses. Two different tests were performed on qPCR data to compare the Cq values obtained: the Student $t$ test was carried out to compare $\mathrm{Cq}$ values between two markers, whereas one-way analysis of variance was used for the comparison of $\mathrm{Cq}$ values between fruits, and the means were compared using the Tukey test at the $P<0.05$ level.

\section{Results}

Selection of $X$. arboricola pv. juglandis-specific DNA markers for qPCR. Nine $X$. arboricola pv. juglandis-specific DNA markers (XAJ1 to XAJ9) were previously described and characterized by Fernandes et al. (2017). The occurrence of these nine markers was investigated in 18 fully sequenced genomes of $X$. arboricola pv. juglandis strains isolated from walnut plant organs. XAJ1, XAJ4, and XAJ6 were present in all genomes, whereas XAJ8 was not present in one of the 18 genomes analyzed. Although the other markers were $X$. arboricola pv. juglandis-specific, they were absent from some $X$. arboricola pv. juglandis strains: marker XAJ9 was present in seven genomes, XAJ7 and XAJ5 in three genomes, and XAJ2 in only one genome. These results were further validated in a collection of $108 \mathrm{X}$. arboricola pv. juglandis tested for the presence of XAJ
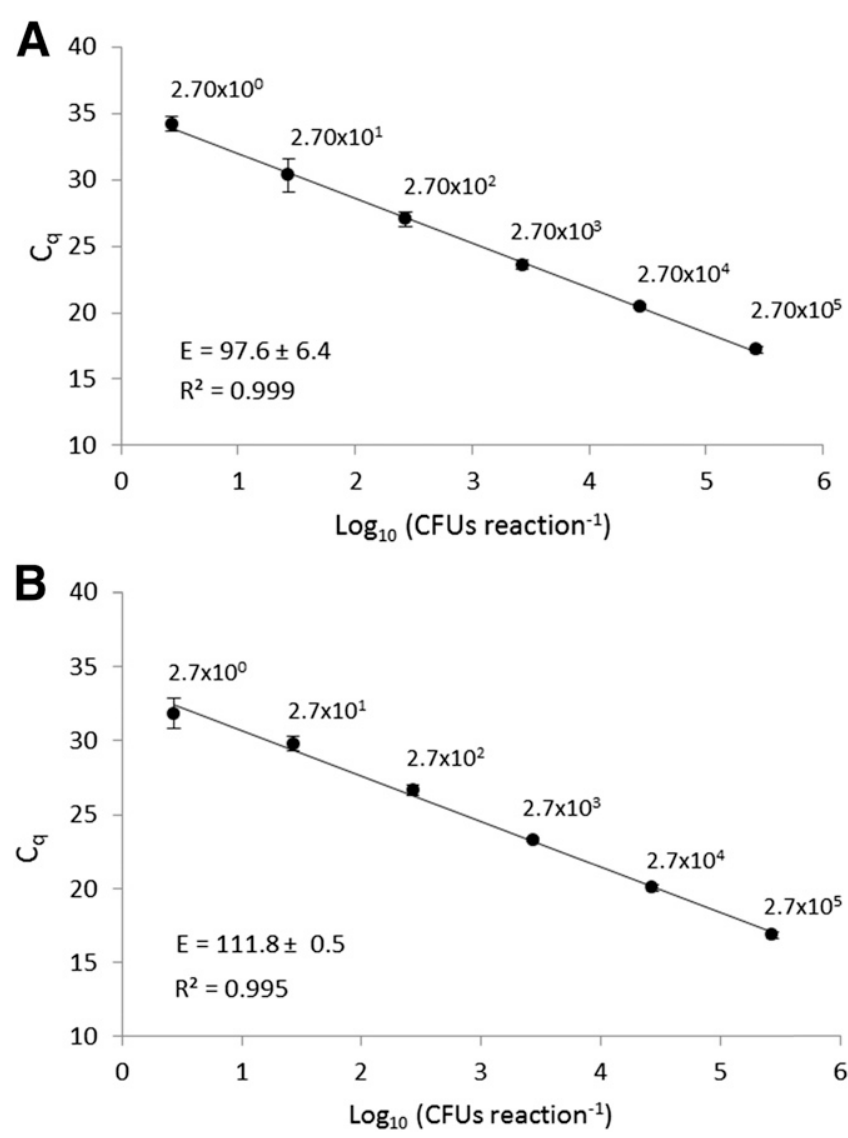

Fig. 3. Standard curves for A, XAJ1 and B, XAJ6 DNA markers obtained from serial dilutions of sample processing control (SPC) samples. The linear portion of the curve ranged from SPC-0 $\left(2.7 \times 10^{5} \mathrm{CFU} / \mu \mathrm{l}\right)$ to SPC-5 $\left(2.7 \times 10^{0} \mathrm{CFU} / \mu \mathrm{l}\right)$. The efficiency $(\mathrm{E})$ of the qPCR assays was $97.6 \pm 6.4 \%$ for XAJ1 and $111.8 \pm 0.5 \%$ for XAJ6. The correlation efficiency $\left(R^{2}\right)$ was 0.999 for XAJ1 and 0.995 for XAJ6. Standard deviations at each point are represented in the figure. $\mathrm{Cq}=$ quantification cycle. 
markers by dot blot hybridization (Fernandes et al. 2018). The data revealed that XAJ1 was present in 108 isolates $(100 \%)$, XAJ2 in 19 isolates (18\%), XAJ3 in 57 isolates (53\%), XAJ4 in 102 isolates (94\%), XAJ5 in 53 isolates (49\%), XAJ6 in 108 isolates (100\%), XAJ7 in 34 isolates (31\%), XAJ8 in 100 isolates (93\%), and XAJ9 in 70 isolates $(65 \%)$. Altogether, these data allowed us to identify XAJ1 and XAJ6 as the most reliable markers to detect and identify $X$. arboricola pv. juglandis and were chosen for further analysis.

A BLAST analysis of the XAJ1 and XAJ6 marker sequences, obtained from X. arboricola pv. juglandis strain NCPPB 1447 (accession number PRJNA84273), showed that the best nontarget BLAST hit for qPCR marker XAJ1 (100 bp) was obtained with $X$. campestris pv. campestris strain 17 (E-value $=2 \mathrm{e}-04$, query coverage $=51 \%)$. Concerning the XAJ6 qPCR marker $(101 \mathrm{bp})$ the best nontarget blastn hit was obtained with $X$. axonopodis pv. phaseoli strain ISO18C8 $(\mathrm{E}$-value $=5.4$, query coverage $=14 \%)$.

qPCR calibration curves for markers XAJ1 and XAJ6. After selection of $X$. arboricola pv. juglandis-specific markers XAJ1 and XAJ6 and design of the qPCR primer pairs, two qPCR calibration curves for each marker were generated using 10-fold dilutions of $X$. arboricola pv. juglandis LMG $747^{\mathrm{T}}$ chromosomal DNA and 10-fold dilutions of DNA extracted from walnut samples spiked with $X$. arboricola pv. juglandis LMG $747^{\mathrm{T}}$ bacteria (SPCs). The qPCR calibration curves obtained with chromosomal DNA revealed an efficiency of 98.7 and $96.4 \%$ for XAJ1 and XAJ6, respectively, and an $R^{2}$ value of 0.990 for both markers (Fig. 2). Taking into account that in silico analyses showed that both markers occur as a single copy locus within the chromosome of the sequenced X. arboricola pv. juglandis, the standard curves allowed estimation of an LOD of 35 chromosomes/qPCR reaction for both markers. The SPC standard curves obtained from three independent experiments with three replicates each resulted in an average efficiency of $97.6 \pm 6.4$ and $111.8 \pm 0.5 \%$ and $R^{2}$ values of 0.999 and 0.995 for XAJ1 and XAJ6, respectively (Fig. 3). The LOD obtained for SPC was determined as $2.7 \mathrm{CFU} / \mathrm{qPCR}$ reaction for both markers.

qPCR repeatability, reproducibility, and specificity. Repeatability (i.e., intra-assay variability) of SPCs revealed a CV of Cq values that ranged from a minimum of $0.58 \%$ (SPC-0) to a maximum of $1.39 \%$ (SPC-4) for the XAJ1 marker and from a minimum of $0.16 \%$ (SPC-0) to a maximum of $0.61 \%$ (SPC-4) for the XAJ6 marker (Tables 3 and 4). Regarding reproducibility (i.e., interassay variability), the $\mathrm{CV}$ values of $\mathrm{Cq}$ ranged from a minimum of 0.79 (SPC-2) to a maximum of $3.67 \%$ (SPC-5) for XAJ1 and from a minimum of 0.54 (SPC-3) to a maximum of $1.55 \%$ (SPC-5) for XAJ6, taking into account three independent experiments (Tables 3 and 4).

Assessment of qPCR specificity for both markers showed that all tested $X$. arboricola pv. juglandis strains gave identical average $\mathrm{Cq}$ values for XAJ1 $(13.38 \pm 1.00)$ and XAJ6 (13.12 \pm 0.84$)$ (Table 5). With only $X$. arboricola pv. juglandis isolate $\mathrm{CPBF}$ 1514, the Cq value was 32.98 for XAJ6 but 11.63 for XAJ1, which is within the $\mathrm{Cq}$ average obtained for this marker with all other $X$. arboricola pv. juglandis strains tested. On the contrary, the Cq values of $X$. arboricola strains not belonging to the juglandis pathovar doubled the $\mathrm{Cq}$ values obtained for $X$. arboricola pv. juglandis strains (>29.21) or showed no amplification for both markers, with the exception of $X$. arboricola pv. celebensis LMG 677 and X. arboricola pv. corylina LMG 689, which showed Cq values of 12.22 and 19.96 for XAJ1, respectively. In addition, the Cq values for strains of other Xanthomonas species were at least twofold higher $(>29.96)$ than the average $\mathrm{Cq}$ values for $X$. arboricola $\mathrm{pv}$. juglandis or revealed no amplification for both markers, except for Xanthomonas sp. CPBF 98 with a Cq value of 12.94 for XAJ1 (Table 5).

PCR detection and qPCR quantification of $X$. arboricola pv. juglandis in infected walnut fruits. To confirm walnut fruit infection with $X$. arboricola $\mathrm{pv}$. juglandis and dismiss the occurrence of possible inhibitory PCR compounds, a preliminary detection PCR was carried out using DNA extracted from walnut fruit epicarp tissues. The results showed PCR amplification for both markers (XAJ1 and XAJ6) in at least one of the one-eighth parts of the five tested fruits (fruits A to E)
(Fig. 4), although a higher PCR efficiency was generally obtained with $\mathrm{XAJ} 1$. Interestingly, for some of the one-eighth fruit samples and regardless of the symptomatic evidence of infection, no amplification was observed whatever the marker, as shown with one-eighth fruit parts B2, B6, and B8 from fruit B (Fig. 4).

When DNA extracted from each of the one-eighth parts of the five studied walnut fruits was used as a template for qPCR, full detection efficiency was achieved, even with the fruit parts for which standard PCR using the same markers was negative (Fig. 4; Table 6). Furthermore, the Cq values obtained for XAJ1 and XAJ6 were consistent between each other and among the different fruit parts, because no statistically significant differences were observed between the $\mathrm{Cq}$ average values obtained for both markers within the same fruit (Table 6). When comparing the average Cq values obtained for both markers and the five fruits studied, only fruit A was shown to be significantly different relative to the $\mathrm{Cq}$ obtained for the other fruits (Table 6).

\section{Discussion}

Considerable advances were made in the last decade concerning amplification-based methods for detection of phytopathogenic bacteria. Specifically, the improvements associated with real-time PCR and LAMP technologies, the access to extensive genomic data, which is instrumental for identifying specific DNA markers and designing better primers, and the progress obtained with more efficient thermostable DNA polymerases led to major advances in cultureindependent methods of phytopathogen detection.

Currently, real-time PCR is acknowledged as cost-effective, high throughput, and capable of providing fast and accurate diagnostics of a broad range of diseases caused by bacteria, as reviewed by Mirmajlessi et al. (2015). Because of its efficiency and specificity, real-time

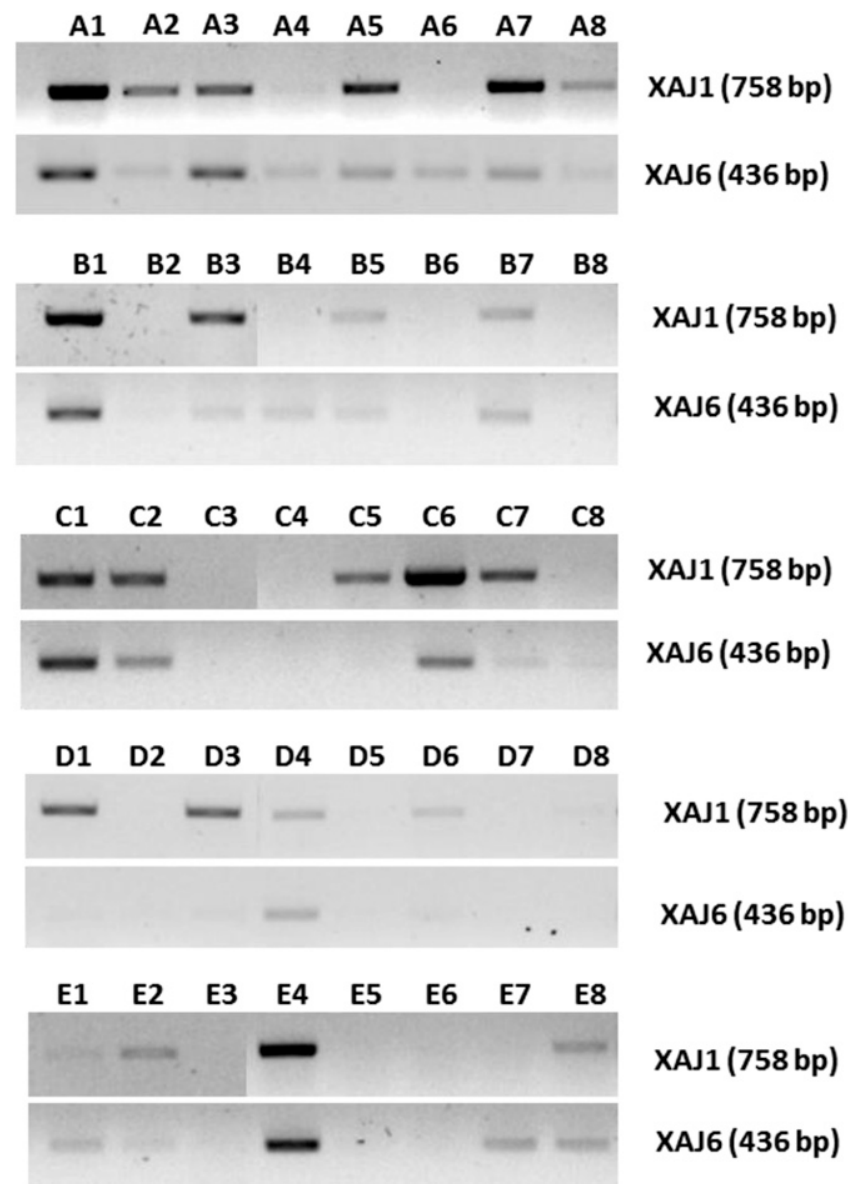

Fig. 4. PCR analysis of infected walnut fruits with DNA markers XAJ1 (758 bp) and XAJ6 (436 bp) for detection of Xanthomonas arboricola pv. juglandis. 
PCR is presently considered the "gold standard" method for phytopathogen detection (Alemu 2014). In fact, qPCR has been used for a panoply of solutions that are beyond detection of phytopathogenic bacteria in plant samples, namely to evaluate the growth of a pathogen in resistance studies with transgenic plants (Hanke et al. 2003; Reynoird et al. 1999), after application of fireblight control agents such as prohexadione calcium (Costa et al. 2001), and in breeding programs (Norelli et al. 2003), and to estimate the extent of contamination with Erwinia amylovora on fruits (van der Zwet and Bell 1990). Despite these advances, not many qPCR protocols have been proposed for quantifying phytopathogenic microorganisms in general and bacteria in particular. A major difficulty in optimizing qPCR protocols to detect and quantify phytopathogenic bacteria in plant samples is mainly attributable to the difficulty in identifying short species-specific DNA signatures suitable for qPCR (i.e., generally $<200 \mathrm{bp}$ ). This is particularly pertinent for phytopathogens such as $X$. arboricola pv. juglandis, which are characterized by high genetic diversity and closely related to nonpathogenic Xanthomonas species.
Fernandes et al. (2017) identified and validated nine $X$. arboricola pv. juglandis-specific DNA markers (XAJ1 to XAJ9), using a comprehensive BLAST analysis of all open reading frames (>100 bp) retrieved from the draft genome of $X$. arboricola pv. juglandis (NCPPB 1447, LMG 751), filtered for high and exclusive similarity toward $X$. arboricola pv. juglandis. The occurrence of these DNA markers in a genetically diverse collection of $X$. arboricola pv. juglandis strains, including $18 \mathrm{X}$. arboricola pv. juglandis genomes and 108 field isolates, allowed identification of markers XAJ1 and XAJ6 as being present in all 126 X. arboricola pv. juglandis strains analyzed and therefore as promising targets for qPCR. Although the other markers $X$. arboricola pv. juglandis were specific, they were absent from some $X$. arboricola pv. juglandis strains, which could lead to false-negative qPCR results. Interestingly, XAJ1 was not present in the two fully sequenced nonpathogenic strains CFBP 7634 and 7651, whereas XAJ6 was present in the nonpathogenic CFBP 7634 but not in 7651, which raises the question of the importance for pathogenicity and virulence of the genomic regions were these

Table 6. Quantification cycle $(\mathrm{Cq})$ values of qPCR quantification of infected walnut fruits with DNA markers XAJ1 and XAJ6

\begin{tabular}{|c|c|c|c|c|c|c|c|c|}
\hline \multirow[b]{2}{*}{ Fruit } & \multicolumn{4}{|c|}{ XАJ1 } & \multicolumn{4}{|c|}{ XАJ6 } \\
\hline & $\mathrm{Cq}^{\mathbf{w}}$ & Mean \pm SD $^{\mathbf{x}, y}$ & Bacterial load $\left(\times 10^{3}\right)^{z}$ & $\operatorname{Mean}\left(\times 10^{3}\right)^{x}$ & $\mathrm{Cq}^{\mathrm{w}}$ & Mean \pm SD $^{\mathbf{x}, y}$ & Bacterial load $\left(\times 10^{3}\right)^{z}$ & $\operatorname{Mean}\left(\times 10^{3}\right)^{x}$ \\
\hline \multirow[t]{8}{*}{$\overline{\mathrm{A}}$} & 24.3 & & 46.1 & & 23.7 & & 36.7 & \\
\hline & 28.6 & & 8.90 & & 27.9 & & 5.47 & \\
\hline & 25.3 & & 45.0 & & 24.8 & & 33.6 & \\
\hline & 28.3 & $27.01 \pm 1.98^{\mathrm{a}}$ & 9.86 & $21.1 \pm 16.9$ & 27.5 & $26.36 \pm 1.85^{\mathrm{a}}$ & 6.55 & $15.2 \pm 13.4$ \\
\hline & 26.4 & & 19.2 & & 25.7 & & 14.0 & \\
\hline & 28.2 & & 7.63 & & 27.6 & & 4.76 & \\
\hline & 25.2 & & 28.0 & & 24.8 & & 17.9 & \\
\hline & 29.8 & & 4.01 & & 28.9 & & 2.52 & \\
\hline \multirow[t]{8}{*}{$\mathrm{B}$} & 26.6 & & 21.6 & & 26.8 & & 15.4 & \\
\hline & 31.9 & & 2.20 & & 31.7 & & 1.55 & \\
\hline & 30.8 & & 4.60 & & 30.7 & & 3.10 & \\
\hline & 27.8 & $30.88 \pm 2.66^{\mathrm{b}}$ & 11.2 & $6.22 \pm 6.98$ & 26.4 & $30.48 \pm 2.6^{b}$ & 15.0 & $5.31 \pm 6.13$ \\
\hline & 31.8 & & 2.99 & & 31.4 & & 2.23 & \\
\hline & 33.5 & & 1.60 & & 33.2 & & 1.09 & \\
\hline & 30.2 & & 4.29 & & 30.4 & & 2.97 & \\
\hline & 34.4 & & 1.28 & & 33.2 & & 1.18 & \\
\hline \multirow[t]{8}{*}{$\mathrm{C}$} & 25.8 & & 23.7 & & 26.0 & & 18.4 & \\
\hline & 29.0 & & 8.00 & & 29.2 & & 5.32 & \\
\hline & 35.3 & & 0.537 & & 35.4 & & 0.265 & \\
\hline & 36.1 & $31.00 \pm 3.49^{b}$ & 0.553 & $6.38 \pm 8.05$ & 35.2 & $31.12 \pm 3.24^{\mathrm{b}}$ & 0.416 & $4.43 \pm 6.20$ \\
\hline & 31.8 & & 1.51 & & 32.4 & & 0.728 & \\
\hline & 28.0 & & 11.8 & & 28.5 & & 7.29 & \\
\hline & 30.7 & & 2.52 & & 31.1 & & 1.38 & \\
\hline & 31.3 & & 2.40 & & 31.2 & & 1.59 & \\
\hline \multirow[t]{8}{*}{$\mathrm{D}$} & 31.7 & & 2.57 & & 32.2 & & 1.28 & \\
\hline & 32.0 & & 1.73 & & 32.2 & & 0.975 & \\
\hline & 30.6 & & 3.44 & & 30.9 & & 1.99 & \\
\hline & 29.0 & $32.31 \pm 2.03^{b}$ & 5.12 & $2.20 \pm 1.51$ & 29.2 & $32.51 \pm 1.87^{b}$ & 3.39 & $1.27 \pm 1.01$ \\
\hline & 33.9 & & 1.11 & & 34.0 & & 0.567 & \\
\hline & 32.2 & & 2.15 & & 32.6 & & 1.09 & \\
\hline & 35.5 & & 0.491 & & 35.1 & & 0.340 & \\
\hline & 33.6 & & 1.03 & & 33.9 & & 0.502 & \\
\hline \multirow[t]{8}{*}{$\mathrm{E}$} & 29.8 & & 4.71 & & 29.7 & & 3.34 & \\
\hline & 31.7 & & 2.54 & & 31.3 & & 1.89 & \\
\hline & 33.4 & & 1.25 & & 33.2 & & 0.803 & \\
\hline & 27.6 & $31.5 \pm 2.49^{b}$ & 18.7 & $5.36 \pm 5.78$ & 27.6 & $31.9 \pm 2.21^{b}$ & 14.0 & $3.94 \pm 4.33$ \\
\hline & 34.2 & & 1.58 & & 33.8 & & 1.06 & \\
\hline & 34.8 & & 1.57 & & 33.6 & & 1.44 & \\
\hline & 29.9 & & 6.28 & & 29.8 & & 4.65 & \\
\hline & 30.6 & & 6.21 & & 30.5 & & 4.26 & \\
\hline
\end{tabular}

$\mathrm{v}$ The Xanthomonas arboricola pv. juglandis quantity is expressed as chromosomes per gram of fresh weight walnut fruit tissue.

${ }^{w} \mathrm{Cq}$ values from qPCR reactions are mean values from samples run in triplicate (technical replicates).

$\mathrm{x}$ Data are means $\pm \mathrm{SD}$ of $\mathrm{Cq}$ values obtained from all fruit parts for each fruit.

y The independent-samples $t$ test was used to determine statistically significant differences between the Cq values obtained with markers XAJ1 and XAJ6 for each fruit. One-way analysis of variance was applied to ascertain statistically significant differences between Cq values for each fruit for the same marker. Values followed by different superscript letters indicate statistically significant differences in $\mathrm{Cq}$ among different fruits for $P<0.05$.

z Bacterial load of $X$. arboricola pv. juglandis. 
markers are located. Although marker XAJ1 was assigned to an intergenic region, marker XAJ6 is part of a putative coding region annotated as a hypothetical protein (Fernandes et al. 2017), which currently makes it difficult to relate these markers with genetic determinants of pathogenicity and virulence.

Conventional PCR amplification of markers XAJ1 (758 bp) and XAJ6 (436 bp) from DNA extracted from infected fruit samples did not reveal the presence of PCR inhibitors co-extracted during DNA extraction, confirming results previously reported (Fernandes et al. 2017). Furthermore, although it was not possible to detect the presence of each marker in all one-eighth fruit parts of the five fruits assayed by conventional PCR, higher efficiency was generally observed for XAJ1 compared with XAJ6, as described by Fernandes et al. (2017).

Aiming to optimize a qPCR method to quantify $X$. arboricola $\mathrm{pv}$. juglandis in infected walnut plant samples and to make these markers suitable to ensure a high qPCR efficiency, a set of primer pairs was designed to amplify a smaller region of each marker (namely, $100 \mathrm{bp}$ for XAJ1 and $101 \mathrm{bp}$ for XAJ6). These qPCR targets are within the size range recommended for qPCR (Bustin et al. 2009). The calibration curves obtained resulted in an efficiency $>96 \%$ and a $R^{2}$ value of 0.99 for both markers, regardless of the DNA template (i.e., $X$. arboricola pv. juglandis chromosomal DNA or DNA extracted from walnut spiked samples), indicating high stability of the qPCR assay (Johnson et al. 2013). The calibration curves allowed us to determine the LOD as 35 chromosomes/qPCR reaction for both markers, using serial dilutions of $X$. arboricola pv. juglandis chromosomal DNA and considering that both markers occur as single copies in the $X$. arboricola pv. juglandis genome, whereas the LOD for spiked samples was as low as $2.7 \mathrm{CFU/qPCR}$ reaction. qPCR repeatability (i.e., intra-assay variation) and reproducibility (i.e., interassay variation) of three independent experiments revealed maximum $\mathrm{CV}$ values of 1.39 and $3.67 \%$ for intra-assay and interassay variation, respectively, for both markers. These data indicate consistent calibration curves, which is particularly important to accurately determine the bacterial load of environmental samples (Almeida et al. 2018).

Aside from the technical validations addressed above, good qPCR specificity is essential to ensure high confidence, particularly when the microbial target is in a complex matrix such as plant samples, frequently characterized by rich microbiota (Brader et al. 2017). In addition, the high genetic diversity of $X$. arboricola, characterized by several pathovars and the existence of closely related other Xanthomonas species, calls for particular attention to achieve a reliable validation of a $\mathrm{qPCR}$ procedure for $X$. arboricola $\mathrm{pv}$. juglandis. In this regard, specificity assays were carried out in 25 $X$. arboricola pv. juglandis strains, seven $X$. arboricola strains not belonging to the juglandis pathovar, and 15 strains of other Xanthomonas species.

Blastn analysis of XAJ qPCR markers showed that the best offtarget values were obtained with $X$. campestris pv. campestris strain $17(\mathrm{E}$-value $=2 \mathrm{e}-04$, query coverage $=51 \%)$ for XAJ1, and with $X$. axonopodis pv. phaseoli strain ISO18C8 (E-value $=5.4$, query coverage $=14 \%$ ) for XAJ6. Because these bacteria are unlikely to share the same ecological niche as $X$. arboricola pv. juglandis, it is not expected that they might lead to false-positive results when assaying infected walnut plant samples. Importantly, given that the present qPCR method is based on two markers (XAJ1 and XAJ6) and that the off-targets are different for both markers, the risk of a false-positive result is negligible.

Regarding the experimental specificity validation, the $\mathrm{Cq}$ values obtained for the target $X$. arboricola pv. juglandis $(\mathrm{XAJ} 1 \approx 13.38 \pm$ 1.00 and $\mathrm{XAJ} 6 \approx 13.12 \pm 0.84$ ) contrasted with the lack of amplification or statistically different higher $\mathrm{Cq}$ values recorded for nontarget species. Interestingly, two of the tested strains (X. arboricola pv. juglandis $\mathrm{CPBF} 1514$ and Xanthomonas sp. CPBF 98) showed $\mathrm{Cq}$ values for XAJ1 within the average range obtained for other $X$. arboricola pv. juglandis strains (11.63 and 12.94, respectively) but high Cq values for XAJ6 (32.98, and 36.71, respectively), characteristic of off-target xanthomonads. These results confirm the presence of
XAJ1 and absence of XAJ6 as shown by dot blot hybridization of these two strains (Fernandes et al. 2017). Multilocus sequence analysis genotyping studies showed that both strains are outside the main clusters of $X$. arboricola pv. juglandis and closer to other $X$. arboricola strains not belonging to the juglandis pathovar or atypical and nonpathogenic walnut $X$. arboricola isolates (Cesbron et al. 2015; Essakhi et al. 2015; Fernandes et al. 2018).

When comparing qPCR and PCR results of infected walnut fruit parts, the former method was shown to be more efficient in $X$. arboricola pv. juglandis detection than conventional PCR, because it was able to detect bacteria in fruit samples where no amplification was observed by conventional PCR (Fig. 4).

In this work, we validated a qPCR approach using two DNA markers able to determine the bacterial load of $X$. arboricola pv. juglandis in infected plant material. Quantification of $X$. arboricola pv. juglandis infecting host plant tissues within a small time frame will allow investigators to measure the virulence fitness of different strains and will support the adequacy of this method to evaluate the tolerance and/or resistance of distinct walnut genotypes to diseases caused by $X$. arboricola pv. juglandis, altogether contributing to improved risk assessment analysis. Taking into account the genetic diversity of $X$. arboricola pv. juglandis and its broad distribution, the rapid identification of highly virulent $X$. arboricola pv. juglandis strains will be particularly useful to inform the implementation of suitable phytosanitary containment measures.

\section{Acknowledgments}

The authors thank Leonor Cruz for laboratory support.

\section{Literature Cited}

Albuquerque, P., Caridade, C. M., Rodrigues, A. S., Marcal, A. R., Cruz, J., Cruz, L., Santos, C. L., Mendes, M. V., and Tavares, F. 2012. Evolutionary and experimental assessment of novel markers for detection of Xanthomonas euvesicatoria in plant samples. PLoS One 7:e37836.

Alemu, C. 2014. Real-time PCR and its application in plant disease diagnostics Adv. Life Sci. Technol. 27:39-49.

Almeida, E., Serra, C. R., Albuquerque, P., Guerreiro, I., Teles, A. O., Enes, P., and Tavares, F. 2018. Multiplex PCR identification and culture-independent quantification of Bacillus licheniformis by $\mathrm{qPCR}$ using specific DNA markers. Food Microbiol. 74:1-10.

Bandi, A., Hevesi, M., Szani, Z., and Magdolna, T. 2015. Assessment of bacterial blight tolerance of Persian walnut based on immature nut test. Not. Sci. Biol. 7 253-257.

Berg, T., Tesoriero, L., and Hailstones, D. L. 2006. A multiplex real-time PCR assay for detection of Xanthomonas campestris from brassicas. Lett. Appl. Microbiol. 42:624-630.

Bos, L., and Parlevliet, J. 1995. Concepts and terminology on plant/pest relationships: Toward consensus in plant pathology and crop protection. Annu. Rev. Phytopathol. 33:69-102.

Brader, G., Compant, S., Vescio, K., Mitter, B., Trognitz, F., Ma, L.-J., and Sessitsch, A. 2017. Ecology and genomic insights into plant-pathogenic and plant-nonpathogenic endophytes. Annu. Rev. Phytopathol. 55:61-83.

Bustin, S. A., Benes, V., Garson, J. A., Hellemans, J., Huggett, J., Kubista, M., Mueller, R., Nolan, T., Pfaffl, M. W., Shipley, G. L., Vandesompele, J., and Wittwer, C. T. 2009. The MIQE guidelines: Minimum information for publication of quantitative real-time PCR experiments. Clin. Chem. 55:611-622.

Casadevall, A., and Pirofski, L. 1999. Host-pathogen interactions: Redefining the basic concepts of virulence and pathogenicity. Infect. Immun. 67:3703-3713.

Casadevall, A., and Pirofski, L. 2001. Host-pathogen interactions: The attributes of virulence. J. Infect. Dis. 184:337-344.

Cesbron, S., Briand, M., Essakhi, S., Gironde, S., Boureau, T., Manceau, C., Fischer-Le Saux, M., and Jacques, M. A. 2015. Comparative genomics of pathogenic and nonpathogenic strains of Xanthomonas arboricola unveil molecular and evolutionary events linked to pathoadaptation. Front. Plant Sci. 6:1126.

Cesbron, S., Pothier, J., Gironde, S., Jacques, M.-A., and Manceau, C. 2014. Development of multilocus variable-number tandem repeat analysis (MLVA) for Xanthomonas arboricola pathovars. J. Microbiol. Methods 100:84-90.

Cho, M. S., Kang, M. J., Kim, C. K., Seol, Y.-J., Hahn, J. H., Park, S. C., Hwang, D. J., Ahn, T.-Y., Park, D. H., and Lim, C. K. 2011. Sensitive and specific detection of Xanthomonas oryzae pv. oryzae by real-time bio-PCR using pathovar-specific primers based on an rhs family gene. Plant Dis. 95:589-594.

Costa, G., Andreotti, C., Bucchi, F., Sabatini, E., Bazzi, C., Malaguti, S., and Rademacher, W. 2001. Prohexadione-Ca (Apogee $®)$ : Growth regulation and reduced fire blight incidence in pear. HortScience 36:931-933. 
Essakhi, S., Cesbron, S., Fischer-Le Saux, M., Bonneau, S., Jacques, M. A., and Manceau, C. 2015. Phylogenetic and variable-number tandem-repeat analyses identify nonpathogenic Xanthomonas arboricola lineages lacking the canonical type III secretion system. Appl. Environ. Microbiol. 81:5395-5410.

Fernandes, C., Albuquerque, P., Cruz, L., and Tavares, F. 2018. Genotyping and epidemiological metadata provides new insights into population structure of Xanthomonas isolated from walnut trees. bioRxiv 397703.

Fernandes, C., Albuquerque, P., Sousa, R., Cruz, L., and Tavares, F. 2017. Multiple DNA markers for identification of Xanthomonas arboricola pv. juglandis isolates and its direct detection in plant samples. Plant Dis. 101:858-865.

Fischer-Le Saux, M., Bonneau, S., Essakhi, S., Manceau, C., and Jacques, M. A. 2015. Aggressive emerging pathovars of Xanthomonas arboricola represent widespread epidemic clones distinct from poorly pathogenic strains, as revealed by multilocus sequence typing. Appl. Environ. Microbiol. 81:4651-4668.

Frutos, D. 2010. Bacterial diseases of walnut and hazelnut and genetic resources. J. Plant Pathol. 92:S79-S85.

Frutos, D., and López, G. 2012. Search for Juglandis regia genotypes resistant/ tolerant to Xanthomonas arboricola pv. juglandis in the framework of COST Action 873. J. Plant Pathol. 94(suppl):S1.37-S1.46.

Garces, F. F., Gutierrez, A., and Hoy, J. W. 2014. Detection and quantification of Xanthomonas albilineans by qPCR and potential characterization of sugarcane resistance to leaf scald. Plant Dis. 98:121-126.

Giovanardi, D., Bonneau, S., Gironde, S., Fischer-Le Saux, M., Manceau, C., and Stefani, E. 2016. Morphological and genotypic features of Xanthomonas arboricola pv. juglandis populations from walnut groves in Romagna region, Italy. Eur. J. Plant Pathol. 145:1-16.

Golmohammadi, M., Cubero, J., Peñalver, J., Quesada, J., López, M., and Llop, P. 2007. Diagnosis of Xanthomonas axonopodis pv. citri, causal agent of citrus canker, in commercial fruits by isolation and PCR-based methods. J. Appl. Microbiol. 103:2309-2315.

Hajri, A., Meyer, D., Delort, F., Guillaumes, J., Brin, C., and Manceau, C. 2010. Identification of a genetic lineage within Xanthomonas arboricola pv. juglandis as the causal agent of vertical oozing canker of Persian (English) walnut in France. Plant Pathol. 59:1014-1022.

Hajri, A., Pothier, J. F., Fischer-Le Saux, M., Bonneau, S., Poussier, S., Boureau, T., Duffy, B., and Manceau, C. 2012. Type three effector gene distribution and sequence analysis provide new insights into the pathogenicity of plantpathogenic Xanthomonas arboricola. Appl. Environ. Microbiol. 78:371-384.

Hanke, V., Geider, K., and Richter, K. 2003. Transgenic apple plants expressing viral EPS-depolymerase: Evaluation of resistance to the phytopathogenic bacterium Erwinia amylovora. Pages 153-157 in: Plant Biotechnology 2002 and Beyond. Springer, Dordrecht, The Netherlands.

Ivanović, Z., Popovic, T., Janse, J., Kojic, M., Stankovic, S., Gavrilovic, V., and Fira, D. 2014. Molecular assessment of genetic diversity of Xanthomonas arboricola pv. juglandis strains from Serbia by various DNA fingerprinting techniques. Eur. J. Plant Pathol. 141:133-145.

Johnson, G., Nolan, T., and Bustin, S. A. 2013. Real-time quantitative PCR, pathogen detection and MIQE. Pages 1-16 in: PCR Detection of Microbial Pathogens. Humana Press, Totowa, NJ.

Kralik, P., and Ricchi, M. 2017. A basic guide to real time PCR in microbial diagnostics: Definitions, parameters, and everything. Front. Microbiol. 8:108

Laala, S., Bouznad, Z., and Manceau, C. 2015. Development of a new technique to detect living cells of Xanthomonas campestris pv. campestris in crucifers seeds: The seed-qPCR. Eur. J. Plant Pathol. 141:637-646.

Lamichhane, J. R. 2014. Xanthomonas arboricola diseases of stone fruit, almond, and walnut trees: Progress toward understanding and management. Plant Dis. 98:1600-1610
Lievens, B., Brouwer, M., Vanachter, A. C., Cammue, B. P., and Thomma, B. P. 2006. Real-time PCR for detection and quantification of fungal and oomycete tomato pathogens in plant and soil samples. Plant Sci. 171:155-165.

Marancik, D. P., and Wiens, G. D. 2013. A real-time polymerase chain reaction assay for identification and quantification of Flavobacterium psychrophilum and application to disease resistance studies in selectively bred rainbow trout Oncorhynchus mykiss. FEMS Microbiol. Lett. 339:122-129.

Mikulic-Petkovsek, M., Slatnar, A., Veberic, R., Stampar, F., and Solar, A. 2011 Phenolic response in green walnut husk after the infection with bacteria Xanthomonas arboricola pv. juglandis. Physiol. Mol. Plant Pathol. 76:159-165.

Mirmajlessi, S. M., Destefanis, M., Gottsberger, R. A., Mänd, M., and Loit, E. 2015. PCR-based specific techniques used for detecting the most important pathogens on strawberry: A systematic review. Syst. Rev. 4:9.

Moragrega, C., Matias, J., Aleta, N., Montesinos, E., and Rovira, M. 2011. Apical necrosis and premature drop of Persian (English) walnut fruit caused by Xanthomonas arboricola pv. juglandis. Plant Dis. 95:1565-1570.

Norelli, J. L., Jones, A. L., and Aldwinckle, H. S. 2003. Fire blight management in the twenty-first century: Using new technologies that enhance host resistance in apple. Plant Dis. 87:756-765.

Palacio-Bielsa, A., Cubero, J., Cambra, M. A., Collados, R., Berruete, I. M., and López, M. M. 2011. Development of an efficient real-time quantitative PCR protocol for detection of Xanthomonas arboricola pv. pruni in Prunus species. Appl. Environ. Microbiol. 77:89-97.

Palacio-Bielsa, A., Lopez-Soriano, P., Buhlmann, A., van Doom, J., Pham, K., Cambra, M. A., Berruete, I. M., Pothier, J. F., Duffy, B., Olmos, A., and Lopez, M. M. 2015. Evaluation of a real-time PCR and a loop-mediated isothermal amplification for detection of Xanthomonas arboricola pv. pruni in plant tissue samples. J. Microbiol. Methods 112:36-39.

Pérez, L. M., Fittipaldi, M., Adrados, B., Morató, J., and Codony, F. 2013. Error estimation in environmental DNA targets quantification due to PCR efficiencies differences between real samples and standards. Folia Microbiol. (Praha) 58: 657-662.

Reynoird, J., Mourgues, F., Norelli, J., Aldwinckle, H., Brisset, M., and Chevreau, E. 1999. First evidence for improved resistance to fire blight in transgenic pear expressing the attacin E gene from Hyalophora cecropia. Plant Sci. 149:23-31.

Robène, I., Perret, M., Jouen, E., Escalon, A., Maillot, M. V., Chabirand, A., Moreau, A., Laurent, A., Chiroleu, F., and Pruvost, O. 2015. Development and validation of a real-time quantitative PCR assay to detect Xanthomonas axonopodis pv. allii from onion seed. J. Microbiol. Methods 114:78-86.

Shapiro-Ilan, D. I., Fuxa, J. R., Lacey, L. A., Onstad, D. W., and Kaya, H. K. 2005. Definitions of pathogenicity and virulence in invertebrate pathology. J. Invertebr. Pathol. 88:1-7.

Surico, G. 2013. The concepts of plant pathogenicity, virulence/avirulence and effector proteins by a teacher of plant pathology. Phytopathol. Mediterr. 52 399-417.

Thomas, S. R., and Elkinton, J. S. 2004. Pathogenicity and virulence. J. Invertebr. Pathol. 85:146-151.

van der Zwet, T., and Bell, R. 1990. Fire blight susceptibility in Pyrus germplasm from Eastern Europe. HortScience 25:566-568.

Vandroemme, J., Baeyen, S., Van Vaerenbergh, J., De Vos, P., and Maes, M. 2008 Sensitive real-time PCR detection of Xanthomonas fragariae in strawberry plants. Plant Pathol. 57:438-444.

Weller, S., Beresford-Jones, N., Hall, J., Thwaites, R., Parkinson, N., and Elphinstone, J. 2007. Detection of Xanthomonas fragariae and presumptive detection of Xanthomonas arboricola pv. fragariae, from strawberry leaves, by real-time PCR. J. Microbiol. Methods 70:379-383. 